\title{
The innovative mode of music culture industry is explored under the background of "Internet Plus"
}

\author{
Weidong $\mathrm{Xu}^{1}$ \\ ${ }^{1}$ Jiangxi University of Applied Science, Nanchang, Jiangxi, China, 330000
}

\begin{abstract}
Culture is the embodiment of a country's social style, as a country's spiritual embodiment, culture can not only bring economic benefits to a country, but also can show a country's social style, the role of culture can not be underestimated. Therefore, this paper is mainly based on the "Internet plus" background of the music and cultural industry innovation model to explore. Mainly for two aspects of research and discussion, the first is the current music and cultural industry facing the development of challenges; the second is the current music and cultural industry innovation model and innovative thinking. At the same time, I hope that enterprises can play a certain role in innovation inspiration. It is hoped that this paper can provide a little reference for the relevant research, so as to lay a solid foundation for the development of the relevant music and cultural industry.
\end{abstract}

\section{CHINA'S MUSIC AND CULTURAL INDUSTRY IS FACING CHALLENGES AT PRESENT}

\subsection{The defects of the contemporary music and cultural industry}

There are still many problems in the music culture under the background of "Internet Plus", among which there are mainly the following aspects: 1 . Lack of professionals. In the field of music culture, professionals have been in short demand, which is an important factor hindering the development of music culture industry. In the training of relevant professionals also have certain limitations, compound talent is very few, can not meet the current music and cultural industry on the cross-border composite talent demand, can not meet the requirements of music creation, music culture industry will not be developed. 2. Insufficient innovation ability. The norms and systems that already exist in the traditional music system have been perfected. Therefore, the music culture will be bound by the traditional music system to a certain extent, which leads to the development of music innovation is hindered, the development space is very limited, even if there are many new music works, but the real acceptance of innovative music works is not much. Most music works tend to meet market demand rather than really attach importance to the creative content itself. In addition, many music creations tend to imitate existing music works, which leads to the creation of music works of low quality, there is no novel.

\subsection{Relevant cultural enterprises lack market competitiveness}

Through the rapid development of information network technology, the spread of culture has been unprecedented development. Therefore, the music and cultural industry is also more and more international trend. In recent years, china has many successful cultural export works, such as some domestic TV dramas, movies, novels and so on, the success stories of these cultural works also laid a solid foundation for cultural output. But to a certain extent, these works in the dissemination and performance of Chinese culture is still not enough, music and cultural industry is even more so, the size of music and cultural enterprises are generally relatively small, cultural content production is not perfect, competitiveness is not enough, so it is not possible to produce competitiveness in the cultural market.

\subsection{The relevant enterprise management model is relatively backward}

In the context of the rapid development of contemporary economy, science and technology, social development is changing rapidly, which also raises new challenges for enterprise development, enterprises can only actively learn, absorb the new technology and culture in the current society to keep up with the pace of the times, but in some enterprises, because the manager's own literacy and vision is not open, resulting in a relatively backward management model, managers do not want to open up innovative enterprise management model, so the music and cultural industry is easy to fall into a lag in the deadlock.

\footnotetext{
*Corresponding author's e-mail: 739960103@qq.com
} 


\subsection{The excavation of cultural connotation is not deep enough}

In the development of music culture industry under the background of "Internet Plus", the innovation and development of Internet music has the problem of insufficient excavation of local cultural connotation, and cultural innovation under the background of Internet needs to be carried out in-depth excavation of cultural content, but also pay attention to the organic combination of information technology. In the process of the cultural development of the music culture industry, it is mainly that the excavation of the local traditional culture is not deep enough, so it leads to the lack of cultural connotation of the innovative works of the cultural industry, which is also very unfavorable to the development of the music and cultural industry.

\subsection{The impact of foreign music on China's music and cultural industry}

In the context of "Internet Plus" music dissemination has become and its convenience, with the help of Internet information technology, music culture dissemination has no borders, consumer choices have become rich and diverse, of which Japan, South Korea and Europe and the United States music culture market has the greatest impact. The data are shown in the table below:

TABLEI. THE INFLUENCE OF DIFFERENT COUNTRIES' MUSIC ON DOMESTIC MUSIC MARKET

\begin{tabular}{|c|c|c|c|}
\hline Ranking & Country & Sales & Proportion \\
& & & \\
\hline 1 & America & 44.82 & $34 \%$ \\
\hline 2 & Japan & 44.22 & $80 \%$ \\
\hline 3 & Britain & 13.26 & $49 \%$ \\
\hline 4 & Germany & 12.98 & $75 \%$ \\
\hline 5 & French & 9.08 & $64 \%$ \\
\hline 6 & Australia & 5.07 & $45 \%$ \\
\hline 7 & Canada & 4.54 & $48 \%$ \\
\hline 8 & Brazil & 2.57 & $62 \%$ \\
\hline 9 & Italy & 2.18 & $62 \%$ \\
\hline 10 & Netherland & 2.16 & $58 \%$ \\
\hline 11 & Korea & 1.88 & $55 \%$ \\
\hline 12 & Swedish & 1.77 & $32 \%$ \\
\hline 13 & Spain & 1.67 & $53 \%$ \\
\hline 14 & India & 1.47 & $31 \%$ \\
\hline 15 & Mexico & 1.45 & $63 \%$ \\
\hline 16 & Swiss & 1.29 & $61 \%$ \\
\hline 17 & Belgium & 1.22 & $64 \%$ \\
\hline 18 & Norwegian & 1.18 & $31 \%$ \\
\hline 19 & Austria & 0.96 & $65 \%$ \\
\hline 20 & China & 0.92 & $18 \%$ \\
\hline
\end{tabular}

\subsection{The cultural industry can't keep up with the trend of the times}

Cultural content must have a certain carrier to spread, with the development and progress of information technology, cultural content communication platform has gradually become online, the development of cultural industry would have to carry out multi-dimensional development in order to have a certain competitiveness in the market. Therefore, the integration of cultural industry and information technology can bring new development impetus to the development of music culture industry, thus laying a good foundation for the development of cultural industry.

\subsection{Other Challenges}

Under the background of Internet + the music of the development of cultural industry still faces many problems and challenges, such as in the service mode in the process of the development of music culture did not achieve the result of economic profit, both in terms of external, profitability, there are several reasons for this problem occurred, is one of the main music culture industry is not like other economic industry can produce high profits, music cultural industries in a certain sense also has the certain public property, for example, in some museum, library, the museum is open to the public with social public institutions, Places the public welfare nature of this nature component is bigger, not all are in order to benefit and development, but it also has made in such a cultural industry innovation and development ability is not enough, in this kind of music in the cultural industry the development of cultural industry will not get a lot of change and innovation, also because of this, music culture industry innovation will not get a lot of innovation, this leads to working in this kind of cultural innovation in the industry is not much change, so the atmosphere is against the development of music culture industry innovation and fusion between industry, the music on the innovation and development of cultural industry is very adverse. In terms of external development, the excessive development of some material and cultural heritages has affected many related things, including the environmental pollution and destruction of some culture-related scenic spots, and the great waste of cultural resources and natural resources.

\section{THE RESEARCH ON THE INNOVATIVE MODE OF MUSIC CULTURE INDUSTRY UNDER THE BACKGROUND OF "INTERNET PLUS"}

\subsection{Innovative development strategy of the structure system of music culture industry}

Music culture industry is a complete ecological architecture to some extent, in which music culture creativity, music design industry, leisure and entertainment industry, music publishing industry and so on are all subsysystores in this ecological architecture. Therefore, if we want to develop the music culture industry chain under the background of "Internet plus", we need to innovate the music culture industry. Only in this way can the related music and cultural industry get a steady stream of development and progress. Therefore, the innovation and development of music culture industry is particularly important, innovation as the development focus of music culture industry can make the whole music culture industry develop and progress. The 
development of music culture industry has also led to the development of the game industry, at the same time, leisure and entertainment industry because of the development of music and culture industry ushered in new opportunities for development. Only through the continuous innovation of music culture industry can we meet the demand of people's music culture industry. Therefore, combining music culture industry with leisure and entertainment industry can greatly accelerate the innovation and development of music culture industry.

The innovative development of music and culture industry will also make the film and television industry get great development. Therefore, leisure and entertainment industry and other industries related to music and cultural industries will be developed accordingly. For example, Shanxi Province's music and cultural industry innovation and development is a good example, Shanxi music and cultural industry to make full use of the local beauty, music concerts and music video production will be Shanxi beauty as a background, in this way, not only to promote the cultural beauty of Shanxi, but also let people enjoy the beautiful scenery of the local. In this way, we can form a model of industrial linkage development, make use of local regional characteristics, and give full play to the influence of music and cultural industries on the local area.

\subsection{Develop appropriate innovation incentive policies}

The development of Internet information technology makes the innovation of music culture industry more convenient, it can be said that the development of Internet promotes the development of music culture industry. In the context of "Internet Plus", enterprises can only improve their competitiveness through continuous innovation and development, so that enterprises can be developed. Developing a series of incentive programs in an enterprise can greatly enhance the development and innovation of enterprise technology, so enterprises need to pay attention to the innovation incentive of employees.

\subsection{Innovation of the business model of the music and cultural industry}

In the process of the development of music and culture industry, the innovation of business model plays an important role in the development of enterprises, the essence of which is that enterprises can create new development ideas and ideas in the process of business development. One of the more famous business model analysis model "RCOV" model from three aspects to analyze the enterprise. Under the framework of "RCOV" business model analysis, the author makes a certain generalization of the development history of music culture industry. The aim is to adopt a different strategy for each stage of development, and the following table is the innovation evolution of the "RCOV" business model:

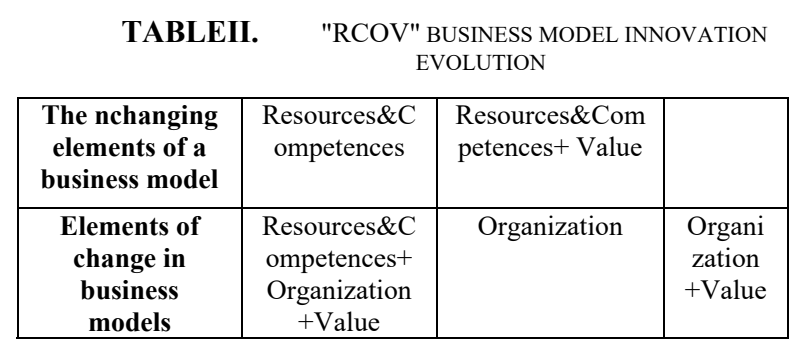

\subsection{Actively explore innovative thinking}

For a cultural enterprise, whether it is the strategic planning for enterprise development, or the management of enterprises, it depends on the thinking and ideas of managers, so the way of thinking of enterprise managers plays a vital role in enterprise development. If the manager of an enterprise is not open-minded enough, he can't lead the cultural enterprise to follow the trend of the times. Even to a certain extent, it will hinder the development and progress of the cultural industry. Therefore, in order to promote the development of music and culture industry, we must start from the following two points: First, pay attention to the development of innovative management mechanism in enterprises; The second is to increase investment in the development of innovative practice. Through a variety of ways to train innovative management personnel, such as enterprise managers to carry out innovative thinking training, training potential professionals to transport high-quality innovation and development talent for enterprises.

\subsection{To dig deep into the cultural content}

In recent years, China has begun to attach importance to the innovation and development of traditional culture, so in the music and cultural industry should also pay attention to the innovation and development of traditional Chinese culture. At the same time, traditional culture can inject new vitality into the music and cultural industry. Especially in the context of "Internet plus" music and cultural industry innovation should follow the following points: First, cultural industry innovation is based on cultural connotation, so on this basis to encourage cultural innovation. And Internet technology can make the process of cultural industry innovation get more support and help. Secondly, we should be positive about cultural innovation, we should be clear about the existing traditional culture, and make use of local tourism resources, cultural relics and some intangible cultural heritage and redeloy their cultural values.

\subsection{Adjust and change the corporate structure of the cultural industry, so as to promote the reform of the music culture industry}

In enterprises need to adjust the structure of the enterprise itself, including enterprise structure and internal management structure need to be adjust, such ability can the enterprise development to a certain extent some of the organizational structure of inertia, so companies need some adjustment on the corporate 
structure could enhance the development efficiency of enterprise, thus lay the effect on the innovative development of cultural industries, and enterprises in the process of innovation and development also should notice to the attention of the theoretical knowledge, only under the guidance of theoretical basis to better direction guidance to practice. It is necessary to avoid as much as possible the constraints brought by the inherent development thinking of enterprises. Only in this way can enterprises develop and innovate smoothly.

In order to achieve certain innovative development, cultural industry must pay attention to two aspects of development. The first is to make full use of information technology under the background of "Internet + " and follow the development trend of The Times. The rational use of big data information will inject new development impetus and innovation foundation into the development of music culture industry. On the other hand, it is necessary to innovate the business model of cultural industry as much as possible, follow the development trend of commercial economy, and explore and innovate the development model of network information sharing, marketing means and so on.

\section{CONCLUSION}

To sum up, culture is not only the foundation of a nation's development, but also plays a cohesive role in the national spirit of a country, making social development more stable and promoting the overall economic development of the country. The development and progress of Internet technology has promoted the development of cultural industry, so the development of music culture industry should be actively integrated with network information technology, only in this way can we maximize the positive impact of music culture industry on social development, while promoting social and economic development.

\section{REFERENCES}

1. Yan Hong. Culture and Art Communication in China under the mode of "Internet $+"[\mathrm{~J}]$. China Ethnic Expo,2020(22):248-250.

2. Li Youwen. Research Overview of "Internet +" Cultural Industry Model Innovation -- From the perspective of industrial chain, supply chain and Value chain $[\mathrm{J}]$. Journal of changjiang normal university,2020,36(05):29-36+125.

3. Zhang Xinmin. Research on international Network Culture Industry Management from the Perspective of Internet $[\mathrm{J}]$. Industry and technology forum,2020,19(18):12-13.

4. Study on the Development Path of cultural industry in the Context of "Internet + " -- A Case study of Chengdu city $[\mathrm{J}]$. Chinese Culture Forum,2020(05):146-153+160.

5. Xiong Qi, Wu Yaxuan. Exploration on the Reform and Innovation Path of Internet Cultural Industry Business Model [J]. Culture Industry,2020(21):116117.

6. Yang Juan. Significance of "Internet + " Music culture Industry to Promote Chinese Folk Songs -- A case study of Shanxi music culture program Song From the Yellow River [J]. Da Guan (Forum),2020(07):30-31.

7. Hong Ying. Exploring The Internet + Cross-border Integration to Promote the Diversified Development of Cultural Industry -- Comment on "Research on the Cross-border Integration and Diversification of Internet + Cultural Industry" [J]. Journal of shanxi university of finance and economics,2020,42(08): 128.

8. Wang Jian. Development status and Path Optimization of cultural industry in the Era of "Internet + " $[\mathrm{J}]$. Guide to Economic Research,2020(10):31-32.

9. $\mathrm{Hu}$ Shaomeng. Research on the International Competitiveness of China's Cultural Industry [D]. Graduate University of Chinese Academy of Social Sciences, 2020.

10. Ding Jie. Theoretical Integration of Music Communication in the Internet Era -- A Brief Review of New Media Music Editing and Communication $[\mathrm{J}]$. China Journal of Radio and Television,2020(01):129.

11. Liu Bo. Analysis on the Harmonious Interaction between new media art and cultural creative Industry [J]. Modern Communication,2019(24):84-85.

12. Deng Chenguang, Zhang Jingjing. New Development of Chinese cultural Industry in the Era of "Internet +" [J]. Journal of Mudanjiang Normal University (Social Science edition),2019(06):51-59.

13. Li Zhuo. Correlation between cultural arts Management and cultural industry development [J]. Think Tank Era,2019(51):213-214.

14. Wang Linsheng, GAO Hongcun. Disorder and Industrial Governance of Internet Cultural Industry from the perspective of media convergence -- 50 national first cases are analyzed [J]. Administrative Reform,2019(12):24-34. 